\title{
Different measures of biodiversity
}

Arising from: X. Irigoien, J. Huisman \& R. P. Harris Nature 429, 863-867 (2004)

$\mathrm{n}$ their analysis of global trends of diversity in marine plankton, Irigoien et al. ${ }^{1}$ find that taxonomic diversity of zooplankton (consumer) is a unimodal function of community biomass that is unrelated to phytoplankton (producer) diversity. Their results are unexpected because in terrestrial organisms primary-producer diversity is a good predictor of consumer diversity ${ }^{2}$. I contend that this apparent uncoupling of producer and consumer diversity in marine plankton is likely to be an artefact due to the authors' use of different measures of diversity for producers and for consumers.

The relationships described by Irigoien et al. ${ }^{1}$ between phytoplankton and zooplankton diversity on a global scale were based on analysis of 100-ml samples examined in an inverted microscope. This method is commonly used for species identification and abundance estimates of phytoplankton, although it underestimates the diversity of small $(<10 \mu \mathrm{m})$ species $^{3}$. For zooplankton, the same method can furnish estimates only of the diversity of easily distinguishable morphotypes, not of species.

The sample material examined by Irigoien et al. ${ }^{1}$ had been fixed with either Lugol's solution or gluteraldehyde, which in the case of microzooplankton allows reliable species identification in only a very small fraction of cells - namely those with a distinct gross morphology, such as tintinnid ciliates, radiolarians and foraminifera that have 'shells' or skeletons: these identifiable forms generally represent some $5-10 \%$ of the community. For most ciliates and dinoflagellates, identification is, at best, limited to the genus ${ }^{4}$. This fixation method is useful for biomass estimations, enabling ciliates and dinoflagellate cells to be placed in size-shape categories; however, these may or may not have ecological relevance and are unlikely to be of any taxonomic validity.

Moreover, Irigoien et al. ${ }^{1}$ analyse very different population sizes, which might also bias their diversity estimates. Producer and consumer diversity were examined in the same sample, which had relatively few consumers: in $100 \mathrm{ml}$ of surface water, phytoplankton cells number $10^{3}-10^{4}$, compared with $1-10^{2}$ microzooplankton cells. This explains in part why microzooplankton diversity was positively related to biomass or numbers of individuals, and also why a total of only 43 'species' of microzooplankton were encountered in this global study. This number is low; large volumes from a single sampling site can yield 39 species of a numerically minor component of tintinnid ciliate microzooplankton ${ }^{5}$.

I therefore propose that the data presented by Irigoien et al. show a weak relation not between taxonomic diversity of consumers and producers but between the size diversity of consumers and taxonomic diversity of producers. Although there could be a correspondence of diversity in producers and consumers if appropriate estimation measures were to be used, this remains to be investigated.

John R. Dolan

Marine Microbial Ecology Group, Laboratoire de

Océanographie de Villefranche, Université de Paris

VI et CNRS UMR 7093 Station Zoologique, BP 28, 06230 Villefranche-sur-Mer, France

e-mail:dolan@obs-vlfr.fr

doi:10.1038/nature03320

$$
\begin{aligned}
& \text { 1. Irigoien, X., Huisman, J. \& Harris, R. P. Nature 429, 863-867 } \\
& \text { (2004). } \\
& \text { 2. Morin, P. J. \& Fox, J. W. Nature 429, 813-814 (2004). } \\
& \text { 3. Hasle, G. R. in Phytoplankton Manual (ed. Sournia, A.) 125-128 } \\
& \text { (UNESCO, Paris, 1978). } \\
& \text { 4. Gifford, D. J. \& Caron, D. A. in Zooplankton Methodology } \\
& \text { Manual (eds Harris, R. P., Weibe, P. H., Lenz, J., Skjoldal, H. R. } \\
& \text { \& Huntley, M.) 193-221 (Academic Press, London, 2000). } \\
& \text { 5. Cariou, J.-B., Dolan, J. R. \& Dallot, S. J. Plank. Res. 21, } \\
& \text { 1065-1075 (1999). }
\end{aligned}
$$

Irigoien et al. reply - We agree with Dolan's concern that simple morphological traits reveal only part of the zooplankton biodiversity ${ }^{1}$. We argue, however, that this is unlikely to affect our findings ${ }^{2}$.

Dolan doubts the lack of relation between phytoplankton diversity and zooplankton diversity in the world's oceans ${ }^{2}$. He argues that we compared apples with oranges, because our method to identify microzooplankton using simple morphological traits was limited to the genus level and hid microzooplankton diversity at the species level.

This argument applies not only to microzooplankton, but to many other taxonomic groups as well. Ecologists are often confronted with problems of species identity when estimating the diversity of organisms within poorly known groups. This is as true for studies of insects in tropical forests as it is for those of plankton in the oceans. Genetic studies of the taxonomy of small cyanobacteria ${ }^{3}$, of morphologically well established species of diatoms ${ }^{4}$, and of conspicuous organisms as large as the copepods ${ }^{5}$, have all revealed cryptic species. We therefore fully agree with Dolan that our simple methods will have underestimated the diversity at the species level.

However, our metrics would have been biased only if we had compared diversity data obtained by different methods (for example, morphological diversity for phytoplankton compared with genetic diversity for zooplankton). We disagree with Dolan's critique that we used two different measures of diversity. Instead, to avoid bias, our biodiversity estimates of phytoplankton and zooplankton were both based on exactly the same methodology, using only simple morphological traits.

We suggest that the lack of a positive correlation between plant diversity and herbivore diversity in the oceans is real, and can be explained by the broad diet of most marine herbivores. In contrast to many specialized terrestrial herbivores (many insects, for example), most zooplankton species do not rely on their food having a specific taxonomic composition. In terrestrial systems with a tight association between species (such as insects and their host plants), even taxonomic lumping of the sort criticized by Dolan is likely to reveal a positive correlation between plant diversity and herbivore diversity at the level of genus or family. Indeed, a seminal work on plant-insect coevolution in terrestrial systems focuses on the family and genus level ${ }^{6}$.

Perhaps, then, the observed lack of a relationship was an artefact because we did not distinguish enough morphospecies among the microzooplankton? In which case, the alternative hypothesis of an increase in microzooplankton diversity with phytoplankton diversity would predict a decrease in the variance of microzooplankton diversity. However, we found that the variance in microzooplankton diversity was not related to phytoplankton diversity either. Inspection of our data reveals that the lack of a relationship may not be due to an underestimation of microzooplankton diversity, but rather to a relatively high microzooplankton diversity in oligotrophic regions with relatively low phytoplankton diversity. Likewise, a high copepod diversity has been found in oligotrophic areas of the Atlantic Ocean ${ }^{7}$.

The advance of molecular genetic techniques in oceanographic research may resolve the issue. Information on the genetic diversity of marine phytoplankton and zooplankton could confirm our findings ${ }^{2}$ and spur further research ${ }^{8}$ in this direction.

\section{Xabier Irigoien*, Jef Huisman $\dagger$,}

\section{Roger P. Harris $\ddagger$}

${ }^{*}$ AZTI, Arantza eta Elikaigintzarako Institutu Teknologikoa, Herrera Kaia Portualdea, 20110

Pasaia, Spain

e-mail:xirigoien@pas.azti.es

$\dagger$ Aquatic Microbiology, Institute for Biodiversity and Ecosystem Dynamics, University of Amsterdam, Nieuwe Achtergracht 127, 1018 WS Amsterdam, The Netherlands

$\ddagger$ Plymouth Marine Laboratory, Prospect Place,

Plymouth PL1 3DH, UK

doi: $10.1038 /$ nature 03321

1. Dolan, J. Nature doi:10.1038/nature03320 (2005).

2. Irigoien, X., Huisman, J. \& Harris, R. P. Nature 429, 863-867 (2004).

3. Janse, I., Meima, M., Kardinaal, W. E. A. \& Zwart, G. Appl. Environ. Microbiol. 69, 6634-6643 (2003).

4. Orsini, L., Procaccini, G., Sarno, D. \& Montresor, M. Mar. Ecol. Prog. Ser. 271, 87-98 (2004).

5. Goetze, E. Proc. R. Soc. Lond. B 270, 2321-2331 (2003).

6. Ehrlich, P. R. \& Raven, P. H. Evolution 18, 586-608 (1964).

7. Woodd-Walker, R. S., Ward, P. \& Clarke, A. Mar. Ecol. Prog. Ser. 236, 189-203 (2002).

8. Census of Marine Life (www.coml.org) 